\title{
Targeting Gene Expression to the Vascular Wall in Transgenic Mice Using the Murine Preproendothelin-1 Promoter
}

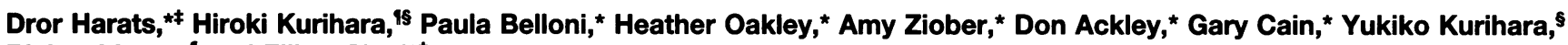 \\ Richard Lawn,' and Elliott Sigal ${ }^{\star *}$ \\ *Syntex Discovery Research, Palo Alto, California 94303; ${ }^{\ddagger}$ Cardiovascular Research Institute, University of California, San Francisco, \\ California; 'Division of Cardiovascular Medicine, Stanford University School of Medicine, Stanford, California; \\ and ${ }^{\S}$ Third Department of Medicine, University of Tokyo, Hongo, Tokyo, Japan
}

\begin{abstract}
To develop a system for overexpressing genes in the vascular wall, we created transgenic mice using the reporter gene luciferase and the murine preproendothelin-1 promoter. In vitro analysis suggested that the murine 5 '-flanking region contained endothelial-specific elements in a 5.9-kb fragment. Five transgenic mice colonies established from independent founders all exhibited the highest level of luciferase activity in the aorta with up to 8,540 light units per microgram of protein. Immunohistochemistry with anti-luciferase antisera revealed high levels of expression in the endothelial cells of both large and small arteries and lower levels of expression in veins and capillaries. Significant expression was also seen in arterial smooth muscle cells and in select epithelial surfaces which is consistent with the known distribution of endothelin-1 in mammals. To further demonstrate the targeting capability of this system, we overexpressed the lipid-peroxidating enzyme, human 15-lipoxygenase, in the vessel wall of transgenic mice. As with luciferase, expression of active enzyme and immunohistochemical localization in vascular cells were documented in transgenic animals. Hence, this new system can be used to direct expression of molecules to the vascular wall for the purpose of examining the biological significance of either overexpression or inhibition of select proteins. (J. Clin. Invest. 1995. 95:1335-1344.) Key words: endothelin-1 • luciferase • endothelium • gene expression • 15-lipoxygenase
\end{abstract}

\section{Introduction}

Atherosclerosis results in the cardiovascular complications of myocardial infarction, stroke, and peripheral vascular disease and is a leading cause of mortality and morbidity. A recent review of the pathophysiology of atherosclerosis lists over 35 potential mediators of this complex disease (1). Because many of these molecules have been identified by in vitro analysis,

D. Harats and H. Kurihara are both considered primary authors due to their equal contributions.

Address correspondence to Elliott Sigal, M.D., Ph.D. Syntex Discovery Research, 3401 Hillview Ave. Palo Alto, CA 94303. Phone: 415354-2211; FAX: 415-354-7554.

Received for publication 17 March 1994 and in revised form 3 October 1994.

J. Clin. Invest.

(C) The American Society for Clinical Investigation, Inc. 0021-9738/95/03/1335/10 $\$ 2.00$

Volume 95, March 1995, 1335-1344 much current research is directed towards analyzing the significance of each of these potential molecular targets in vivo. One powerful new approach that could be useful in such analyses is the creation of transgenic mice which overexpress or inhibit select proteins implicated in the atherogenic process. A limitation in the field has been the lack of a system to target gene expression specifically to the vessel wall. Endothelin-1 is a $21-$ amino acid peptide which was originally characterized as a potent vasoconstrictor synthesized by endothelial cells (2). The expression of endothelin-1 in mammals is fairly specific for the endothelium, although there is some expression in other cells, mainly the airway and gastrointestinal epithelium, neurons, and glomerular mesangial cells $(3-10)$. Endothelin-1 is derived from the prepropeptide preproendothelin-1 which has a promoter region with endothelial cell specificity as assessed by in vitro analysis (11-14). Hence the $5^{\prime}$-flanking region of preproendothelin- 1 would appear attractive for in vivo gene targeting. To avoid any species barrier to high levels of expression, we cloned and utilized the murine promoter region. After determining that larger flanking regions yielded greater expression in vitro, we used firefly luciferase as a reporter gene and determined the in vivo expression of immunoreactive protein and enzymatic activity directed by the 5.9-kb 5'-flanking region. To assure that this approach would yield reasonable levels of expression of a target protein, we also created transgenic mice overexpressing 15-lipoxygenase which has been implicated in the oxidation of low density lipoprotein in atherogenesis (15).

\section{Methods}

Cloning of the murine preproendothelin gene. To obtain genomic clones for the murine preproendothelin-1 (PPET-1) ${ }^{1}$ promoter region, oligonucleotide probes corresponding to the nucleotide sequence of the entire murine endothelin-1 (ET-1) coding sequence (16) were used to screen a BALB/c mouse genomic library (Clontech Laboratories Inc. Palo Alto, CA) under high stringency conditions. DNA sequencing was performed using the dideoxy chain termination method. A fragment containing the 5'-flanking region, of the PPET-1 gene was subcloned, and the transcription start-site was determined by primer extension. All molecular biological procedures were standard $(17,18)$.

Preproendothelin-Luciferase plasmids. To construct plasmids with the firefly luciferase as a reporter gene directed by the murine preproendothelin promoter, an EcoRI digest of the murine PPET-1 genomic fragment, which includes $2.4-\mathrm{kb}$ of the 5 -flanking region, the first exon of the gene and $0.8 \mathrm{~kb}$ of the first intron (Figs. 1 and 2), was subcloned into pBluescript (Stratagene, La Jolla, CA). From this subclone we excised a BamHI fragment which includes $1.4 \mathrm{~kb}$ of the $5^{\prime}$-flanking

1. Abbreviations used in this paper: 15-HETE, 15-hydroxyeicosatetraenoic acid; BSA, bovine serum albumin; ET-1, endothelin-1; PBS, phosphate buffered saline; PPET-1, preproendothelin-1. 
region, the first exon of the gene and $0.8 \mathrm{~kb}$ of the first intron and subcloned it into a second Bluescript plasmid (p1.4PPET-Blu). A BamHI digest of the pGL-basic vector (Promega, Madison, WI) containing the luciferase gene with its own ATG and stop codon as well as the SV40 intron/polyA signal, was cloned into the BglII site in the noncoding region of the first exon in the 1.4PPET-Blu plasmid (Fig. 2). This resulted in the plasmid we used for in vitro studies and was called p1.4mPPET-LUC. We then cut out a BamHI-BamHI fragment from p1.4mPPET-LUC. This fragment contained the $1.4 \mathrm{~kb}$ of the $5^{\prime}$-flanking region, the first exon of the gene with the luciferase gene cloned into its BglII site and the $0.8 \mathrm{~kb}$ of the first intron. By inserting it downstream of a $4.5 \mathrm{~kb}$ HindIII-BamHI fragment from -5.9 to $-1.4 \mathrm{~kb}$ of the murine PPET-1 5'-flanking region we created a vector which contained $5.9 \mathrm{~kb}$ of the 5 -flanking region (p5.9mPPET-LUC) (Fig. 2). The other

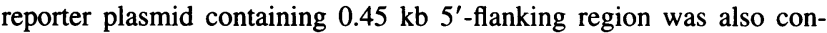
structed in a similar fashion (p0.45mPPET-LUC) (Fig. 2). For creating the plasmids with the 15-lipoxygenase directed by the preproendothelin promoter (pPPET-15LO), the cDNA for the human enzyme was used (19).

Cell culture and DNA transfection. Human umbilical vein endothelial cells (HUVEC) were generously provided by M. Mulkins. HUVEC and the bovine pulmonary artery endothelial cell line, CPAE (American Type Culture Collection, Rockville, MD) were grown on human fibronectin-coated flasks (Biomedical Technologies Inc., Stoughton, MA) in DME supplemented with $20 \%$ fetal calf serum, $150 \mu \mathrm{g} / \mathrm{ml}$ endothelial cell growth supplement (Collaborative Research Inc., Bedford, MA), $0.1 \mathrm{U}$ heparin/ml, $25 \mathrm{mM}$ Hepes (N-2-hydroxyethylpiperazine- $N^{\prime}-2$ ethanesulfonic acid), $1 \mathrm{mM}$ sodium pyruvate, $1 \mathrm{mM}$ non-essential amino acids solution, $50 \mathrm{U}$ penicillin/ml, $50 \mu \mathrm{g}$ streptomycin/ml, and $2 \mathrm{mM}$ glutamine. The murine fibroblast cell line, NIH 3T3, and the monkey kidney cell line, Cos-7, were grown in DEM supplemented with $10 \%$ fetal calf serum, $10 \mathrm{mM}$ Hepes, $50 \mathrm{U}$ penicillin/ml, $50 \mu \mathrm{g}$ streptomycin/ $\mathrm{ml}$, and $2 \mathrm{mM}$ glutamine. All cells were plated in $60-\mathrm{mm}$ dishes at least $24 \mathrm{~h}$ before transfection. DNA transfection of HUVEC, CPAE, NIH 3T3, and Cos-7 cells were performed with lipofectin reagent (GIBCO BRL, Gaithersburg, MD) using standard technique (20). The cells ( $\sim 60 \%$ confluent) were transfected with $6 \mu \mathrm{g}$ of either the PPET-1 luciferase fusion gene plasmids (with $5.9,1.4$, or $0.45 \mathrm{~kb} 5$ '-flanking promoter region) or with the SV40 minimal promoter-luciferase plasmid (pGL2-control vector; Promega). The vector $\mathrm{pSV} \beta$ galactosidase (4 $\mu \mathrm{g}$ ) (Promega) was used as an internal standard for the transfection efficiency. A plasmid with the 5.9-kb 5'-flanking region of the PPET1 promoter and the luciferase gene in the reverse orientation was used as negative control. The cells were harvested $60 \mathrm{~h}$ after transfection and were assayed for luciferase and $\beta$-galactosidase activity.

Luciferase activity assays of cells and tissues. Cells were washed and $250 \mu \mathrm{l}$ lysis buffer (Promega) was added for $15 \mathrm{~min}$. Cell lysates were then micocentrifuged $(16,000 \mathrm{rpm} \times 1 \mathrm{~min})$, and $20 \mu \mathrm{l}$ of the clear supernatants were added to $100 \mu \mathrm{l}$ of luciferase assay buffer (Promega). The activity was measured in a Lumat LB 9501 Luminometer (Berthold, Gaithersburg, MD) over a 20-s period. To assess luciferase activity in mice tails or other organs, tissue $(15 \mathrm{mg})$ was excised and homogenized in $1 \mathrm{ml}$ of $15 \mathrm{mM} \mathrm{KH} \mathrm{PO}_{4} \mathrm{pH} 7.5,1 \mathrm{mM}$ EDTA, $1 \mathrm{mM}$ DTT, and $10 \%$ glycerol. To this homogenate $250 \mu \mathrm{l}$ of $5 \times$ lysis buffer was added (Promega), and the solution was shaken well for $15 \mathrm{~min}$ at room temperature. The solution was then centrifuged $(13,000 \mathrm{~g}, 15 \mathrm{~min})$ and $20 \mu \mathrm{l}$ of the supernatant was assayed in the same manner as for the cells. Nontransgenic mice organs were processed in the same way and used as control. Results were expressed as luciferase light units per $1 \mu \mathrm{g}$ of protein per $20 \mathrm{~s}$. Protein was measured using the Bradford assay with bovine serum albumin (BSA) as a standard (21).

Generation of transgenic mice. The 5.9-kb PPET-1 5'-flanking promoter region-luciferase expression cassette (5.9PPET-LUC) was liberated from the p5.9PPET-LUC by Xhol and NotI digestion, purified by agarose gel electrophoresis and Geneclean kit (Bio 101, Mount Prospect, IL). Purified DNA (1-2 $\mu \mathrm{g} / \mathrm{ml})$ was redissolved in $5 \mathrm{mM}$ Tris, $\mathrm{pH} 7.4$, $0.1 \mathrm{mM}$ EDTA before pronuclear injection. Donor eggs were prepared from C57B6/SJL F1 mice obtained from Jackson Laboratory (Bar Har-

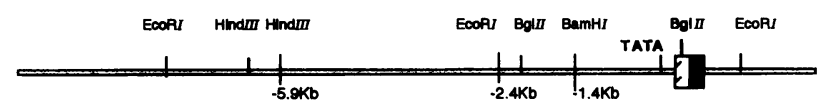

$\overline{\mathrm{Kb}}$

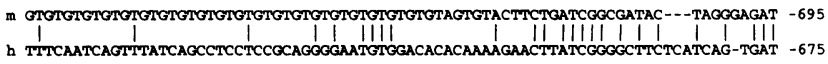
m AAGGATGTACCTGACA-AAACCACATTGTTGTTGTTATCATTATTATTTAGTTPTCCTTCCTTGCTAACTCCTGACGGA -616 m AAGGATGTACCTGACA-AAACCACATTGTTGTTGTTATCATTATPATTTAGTTPTCCTTCCTTGCTAACTCCTGACGGA -616 m ATCTITCTCACCTCAAATGCGAaGtACTPTAGTTTAGAAAAGACTTGGTGGAA-GGGGGGTGGTGGAAAGTAGGGTG -538

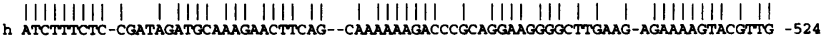
m ATCTICCAAACTAATCTGGTTCCCCGCCCGCCCCAGTAGCTGGGATTCAAGAGCGAAGAGTGGGGATCGTCCCCTTGTT -459

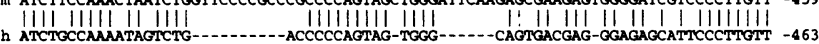

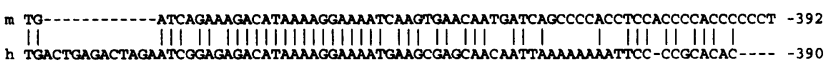
m GCOCGCGCACAATACAATCTATTT-AATTGTACTTCATACTTTTCATTCC AATGGGGTGACTTTGCTTCTGGAG-AAAC -315

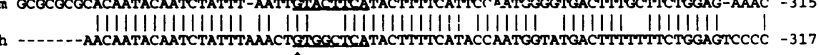

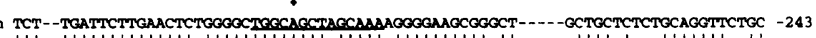

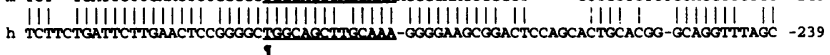

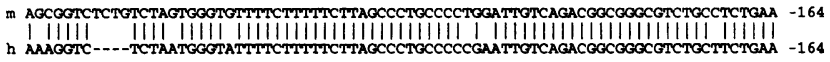
m GTFAGCCOTGATTTCCTCTAGAGCCGGGTCTTATCTCTOGCTGCACGTTOCCTOTGCGTGACTAATCACACMUJAACAT -85

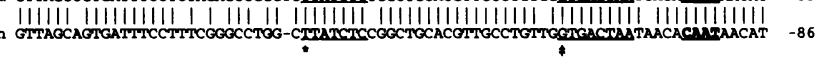

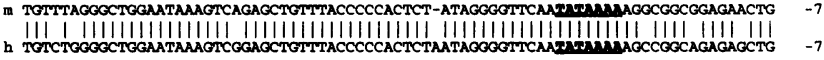
m TCCGAGTCAGACOCGTTCCTGCACCGGCGC--TGAGAGCCTGACCCGGTCTGCTCC-GCTGTCCTTGCGCGCTGCCTCC + 71

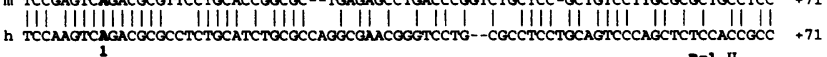
m - СОOCTGCCCOC-GACGCT---TTCOC--CCCAGTGGAGGGC---CACTTGCTGAGGACCGCGCT---GManIII II 137

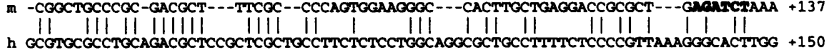

Im AAAAAAACAAAAAACAAAAAACMUAAAACCCAGAGGCGATCAGAGCGACCAGACACCG-TCCTCTTCGTTPTGCATTG + 215

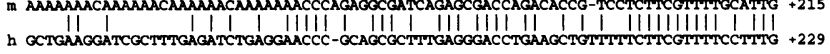
m AGTTCCATPTOCAACCGAGTPTTCTPTPTPTCCTPTPTCCCCACTCTTCTGACCCCTPTECAGANTOGATTATTPTCCC +294

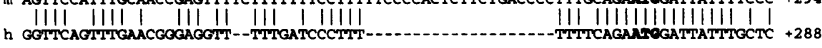
m GTGATCTTCTCTCTGCTGITCOTGACTPTCCAAGGAGCTCCAGAAACAGgtaggcgCcacttgcgaatctttctacttc +373

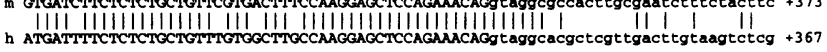

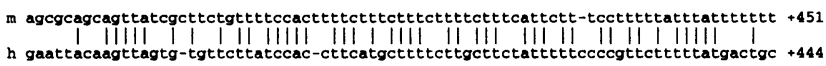

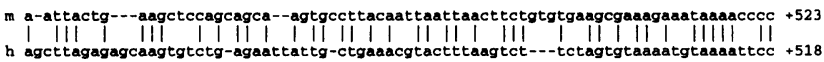
m tgt-ttgaatacagctgactacaaccgagtatcgcatagcttc $\quad+560$

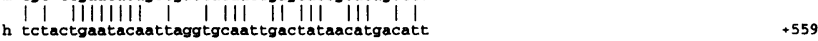

Figure 1. Nucleotide sequence and restriction map of the mouse preproendothelin-1 promoter region. Restriction map: the first exon contains the $5^{\prime}$-noncoding region (hatched) and the $5^{\prime}$ end of the coding region (shaded). The BglII site in the first exon that was used for subcloning of the luciferase gene is indicated in bold type. Location of the putative TATA box is also indicated. Sequence: partial sequence of the promoter region of the murine $(\mathrm{m})$ and the human(h) endothelin-1 gene is presented. Identical sequence is indicated by vertical lines. The transcription start site is indicated by number 1 and nucleotides are numbered from this point. The CAAT and TATA consensus sequences are in bold type and underlined. The GATA-2 binding site, the TPA/AP-1 binding sites, and the NF-1 binding element are indicated by the symbols *, $\ddagger$, and I, respectively. The BgIII site in the noncoding area of the first exon that was used for subcloning of the luciferase gene is indicated. The preproendothelin ATG is indicated in bold type and the first intron in lower case letters

bor, ME). Microinjected eggs were then transferred into the oviducts of CD-1 foster mothers (Charles River Breeding Laboratories, Wilmington, MA) (18). Founder mice were identified by luciferase activity assay of the tails and confirmed by Southern blot analysis of tail DNA using a 360 -bp luciferase gene sequence as probe. Founders with high luciferase activity levels were crossbred for several generations with wild type C57B6/SJL mice to establish heterozygous colonies. PPET-15LO 


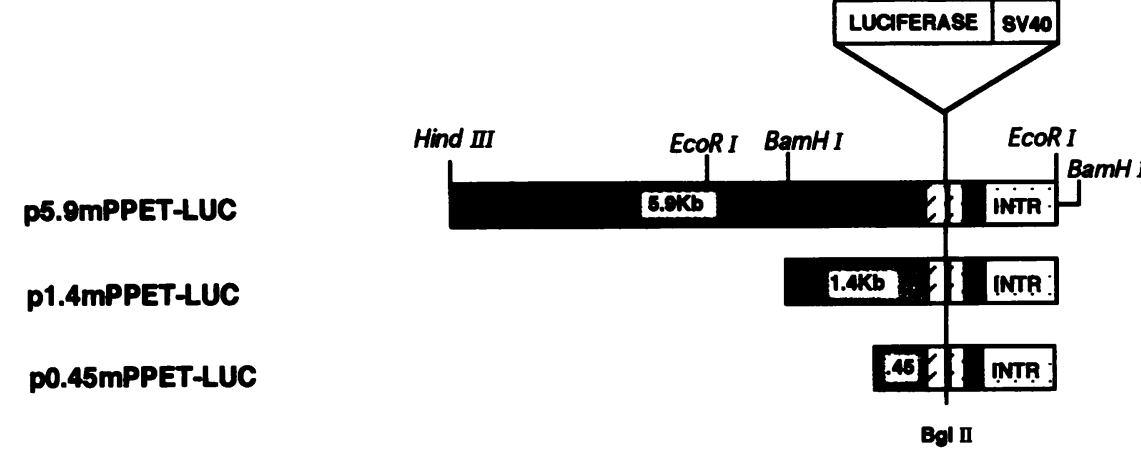

PPET1 5' flanking

PPET1-1et exon noncoding reglon

\section{PPET1-1t exon} coding reglon

8v40 SV40 PAintron
Figure 2: Preproendothelin-luciferase. Each construct contains the 5 '-flanking region of variable length $(5.9,1.4$, and $0.45 \mathrm{~kb})$, the noncoding (hatched) and the coding (shaded) regions of the first exon and $0.8 \mathrm{~kb}$ of the first intron (INTR) of the mouse preproendothelin-I gene. The firefly luciferase gene with its own ATG, stop codon, and the SV40 intron/polyA signal (BamHI digest of the pGLbasic vector; Promega) is inserted in the BglII site in the $5^{\prime}$-noncoding region of exon one upstream to the preproendothelin ATG signal as described in Methods. transgenic mice were created using similar technique. Founders were screened by polymerase chain reaction using primers to the $3^{\prime}$ end of the PPET-1 promoter sequence and the $5^{\prime}$ end of the 15-lipoxygenase cDNA.

Isolation of aortic vessel wall cells. Mouse aortic endothelial and non-endothelial cells were obtained from five transgenic (tg5.9mPPE-

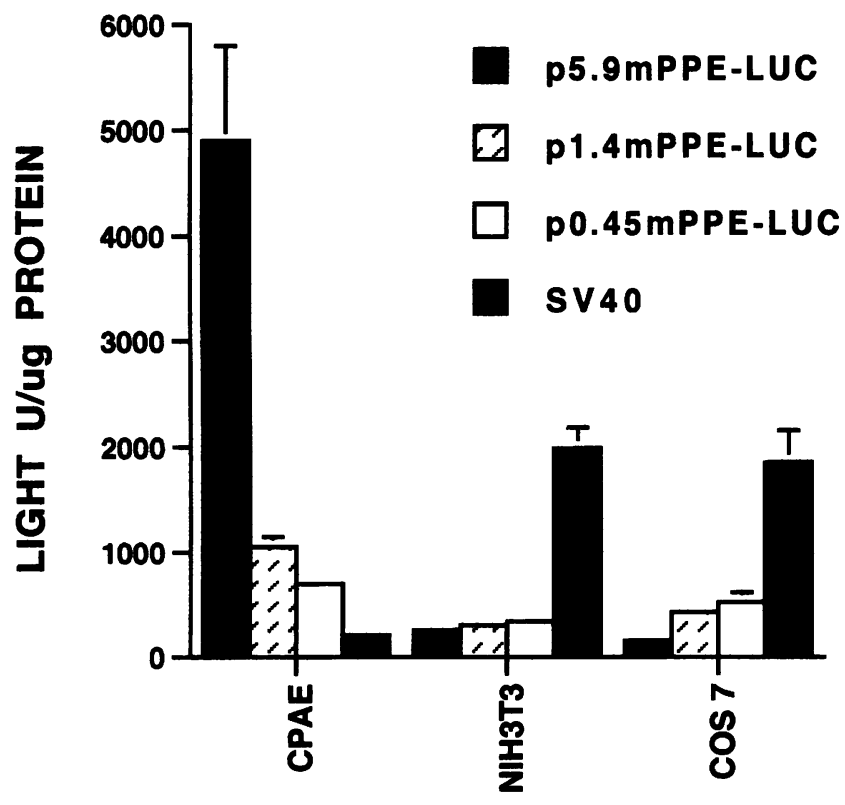

\section{CELL LINES}

Figure 3: Cell-specific expression of the murine preproendothelin-1 gene in vitro. Cell lines were transfected, as described in Methods, with plasmids containing the reporter gene luciferase directed by different fragments $(0.45,1.4$, and $5.9 \mathrm{~kb})$ of the 5 '-flanking region of preproendothelin. Cells were also transfected with the SV40 minimal promoterluciferase plasmid (pGL2-control vector; Promega). The results represent the means and standard deviation of five independent transfections. CPAE, bovine pulmonary artery endothelial cell line; $N I H 3 T 3$, murine fibroblast cell line; $\operatorname{Cos} 7$, monkey kidney cell line.
LUC) and five nontransgenic mice. Aortas were surgically dissected, rinsed in ice cold phosphate buffered saline (PBS), minced to one by one $\mathrm{mm}$ and digested in an enzyme mixture containing DME/F12, 0.5\% BSA, $0.2 \%$ Collagenase, $6 \mathrm{U} / \mathrm{ml}$ Dispase (Collaborative Research, Bedford, MA), and $10 \mu \mathrm{g} / \mathrm{ml}$ DNase (Boehringer Mannheim, Indianapolis, IN). The endothelial and smooth muscle cells were then separated over a Nycodenze gradient and affinity purified over lectin magnetic beads (22). The two fractions were then stained with anti-Von Willebrand antibody to identify endothelial cells (DAKO, Carpinteira, CA).

Immunohistochemistry. Anti-luciferase antisera was generated by immunizing rabbits with luciferase (Sigma Chemical Co., St. Louis, MO) using, in sequence, Freund's complete and incomplete adjuvant and aluminum adjuvant (Pierce, Rockford, IL). As little as $0.5 \mathrm{ng}$ luciferase could be detected by the resulting anti-luciferase serum on immunoblots (1:100 dilution). The appropriate immunoreactive band was detected in immunoblots of extracts of transfected cells and this correlates with the appearance of luciferase activity (data not shown). In contrast, in mock-transfected cells where no luciferase activity is detected, there is no immunoreactive band. Furthermore, non-immune sera does not detect bands on immunoblots of any transfected or mock-transfected cells (data not shown).

To determine the tissue distribution and cellular localization of luciferase expression, both immunoperoxidase and immunofluorescence techniques were used. For immunofluorescence analysis, tissues were prepared by freezing in OCT immediately after necropsy. Serial sections $(10 \mu \mathrm{m})$ were fixed briefly in acetone at $-20^{\circ} \mathrm{C}$. Sections were then

Table I. Luciferase Expression in Tails of 3-wk-old Mice from Different Generations $\left(F_{0}, F_{1}\right.$, and $\left.F_{2}\right)$

\begin{tabular}{lrrr}
\hline \multirow{2}{*}{$\begin{array}{c}\text { Luciferase activitiy } \\
\text { (Light units/mg Protein) }\end{array}$} & \multicolumn{3}{c}{ Number of mice analyzed } \\
\cline { 2 - 4 } & Fo & F1 & F2 \\
\hline Low activity $\left(10-10^{2}\right)$ & 160 & 202 & 50 \\
Medium activity $\left(10^{2}-10^{3}\right)$ & 12 & 16 & 2 \\
High activity $\left(10^{3}-10^{4}\right)$ & 4 & 55 & 27 \\
Total positives & 29 & 24 & 5 \\
& & 95 & 34 \\
\hline
\end{tabular}

Results represent number of animals in each group. 

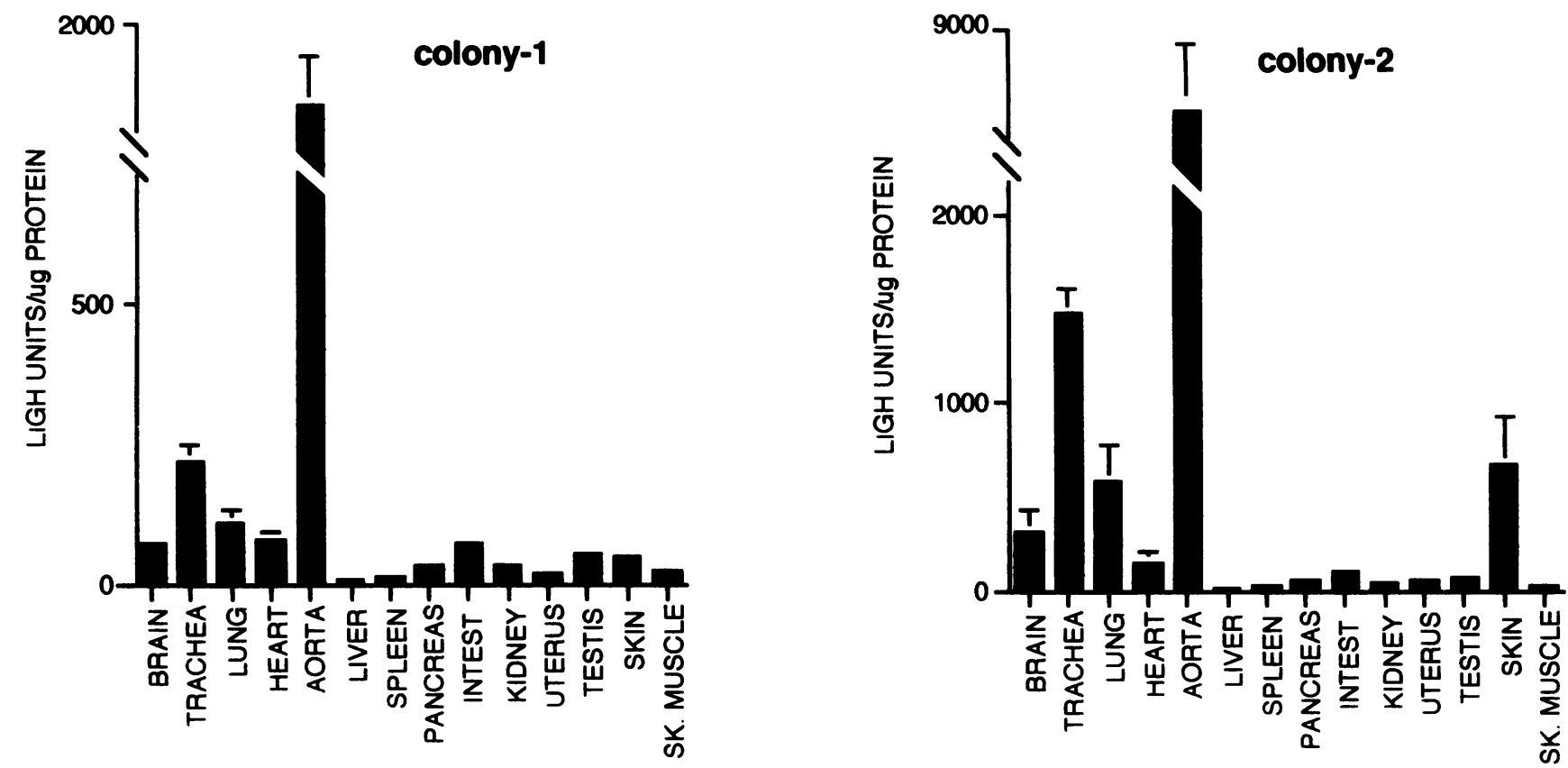

Figure 4. Tissue luciferase activity in two transgenic colonies derived from independent founders. 3-mo-old mice were sacrificed and the tissue expression of luciferase was measured as described in Methods. The mean and standard deviation of luciferase activity (light units per microgram of protein) are shown for mice from the lowest activity colony, tg5.9mPPETLUC-1 $(n=13)$, and from the highest activity colony, tg5.9mPPETLUC$2(n=5)$.

immersed sequentially in PBS containing $0.5 \%$ BSA and $10 \%$ normal goat sera (blocking solution) (10 min), followed by blocking solution containing $10 \mu \mathrm{g} / \mathrm{ml}$ avidin (10 $\mathrm{min})$, blocking solution containing 10 $\mu \mathrm{g} / \mathrm{ml}$ biotin (10 $\mathrm{min})$, and primary rabbit anti-luciferase antisera $1: 500 /$ blocking solution ( $90 \mathrm{~min})$. Bound primary antibody was detected by incubation with biotinylated goat anti-rabbit IgG (1:250) (Vector Labs, Burlingame, CA) followed by streptavidin-FITC (1:200) (Pierce, Rockford, IL). Sections were counter-stained with propidium iodide (Sigma Chemical Co., St. Louis, MO) to identify cellular architecture. Immunofluorescence was detected on a Axiovert Microscope (Leica Inc., Deerfield, IL). Anti-Von Willebrand antibody or anti-smooth muscle-actin antibody (DAKO, Carpinteira, CA) were used to identify endothelial cells or smooth muscle cells, respectively. Transgenic tissue stained with preimmune sera and nontransgenic tissue stained with the luciferase antisera were both used to assess nonspecific fluorescence.

Immunoperoxidase staining was assessed on 5- $\mu \mathrm{m}$ sections prepared from formalin-fixed paraffin embedded tissues. Sections were deparaffinized, and permeabilized with PBS containing $0.2 \%$ Nonident-P40 detergent (Sigma Chemical Co.). Sections were then immersed sequentially in PBS containing $0.5 \%$ BSA and $10 \%$ normal goat sera (blocking solution) (10 min), followed by blocking solution containing $10 \mu \mathrm{g} / \mathrm{ml}$ avidin (10 min), blocking solution containing $10 \mu \mathrm{g} / \mathrm{ml}$ biotin (10 min), and primary rabbit anti-luciferase antisera 1:500/blocking solution (overnight at $4^{\circ} \mathrm{C}$ ). The sections were then incubated with biotinylated goat anti-rabbit IgG (1:250) (Vector Labs), and endogenous peroxidase activity was then quenched with $3 \% \mathrm{H}_{2} \mathrm{O}_{2}$ for $5 \mathrm{~min}$. Bound primary antibody was detected by $\mathrm{ABC}$ (Vector Labs) followed by the substrate, amino-ethyl-carbozole (AEC; Vector Labs) or diamino-benzidine (DAB; Vector Labs), and counterstained with hematoxylin. Transgenic tissue stained with preimmune sera and nontransgenic tissue stained with the luciferase antisera were used to assess nonspecific staining. To determine the tissue distribution and cellular localization of 15 lipoxygenase expression, primary organs were prepared for frozen or paraffin embedded sections as described above for the luciferase staining. Tissue sections were stained with rabbit anti-human 15-lipoxygenase antibody as described previously $(23,24)$.

15-lipoxygenase enzymatic activity. To assess the level of expression of the human 15-lipoxygenase in the transgenic mice, we performed enzyme activity assay on various tissues and measured the enzyme product, 15-hydroxyeicosatetraenoic acid (15-HETE) by modification of the standard HPLC technique $(23,25)$. Briefly, transgenic and nontransgenic control mice were killed and perfused with cold saline (left ventricle to right atrium). Organs were then harvested, trimmed from the fat and the connective tissue around them, weighed, minced, and resuspended in $1 \mathrm{ml}$ of cold PBS, $5 \mathrm{mM}$ glucose, $\mathrm{pH}$ 7.4. About 200 $\mathrm{mg}$ tissue was used for each activity assay. In small organs such as the aorta (5 to $12 \mathrm{mg}$ each) we combined three mice as one sample. The reactions were carried out in $1 \mathrm{ml}$ at $37^{\circ} \mathrm{C}$ for $15 \mathrm{~min}$, using $20 \mu \mathrm{M}$ cold arachidonic acid and $2 \mu \mathrm{ci} \mathrm{C}^{14}$ arachidonic acid as a substrate for the lipoxygenase. The reaction was terminated with $100 \mu \mathrm{l}$ glacial acetic acid and the lipids were extracted with one volume of isopropyl-alcohol and one volume of chloroform (23). An aliquot of prostaglandin $B_{2}$ was used as an internal standard. All extracts were dried under $\mathrm{N}_{2}$ and stored at $-70^{\circ} \mathrm{C}$. Extracts were reconstituted in chromatography solvent and were analyzed by reverse-phase HPLC on a Shimadzu CR4-A chromatography system using Adsorbosil C18 column $(5 \mu \mathrm{m}, 4.6 \mathrm{~mm} \times 25$ $\mathrm{cm}$, Alltec). The column was developed at a flow rate of $1.0 \mathrm{ml} / \mathrm{min}$ by a gradient program using two solvents (A and $\mathrm{B}$ ) set at $55 \%$ B for 0 $16 \mathrm{~min}, 70 \% \mathrm{~B}$ for $17-37 \mathrm{~min}, 100 \%$ B from $38-56 \mathrm{~min}$, and $55 \%$ B for 56-60 min. Solvent-A was methanol/water/acetic acid (50:50:0.01) and B was methanol/water/acetic acid (90:10:0.01). The HPLC eluate was monitored using a Shimadzu SPD-6AV detector set at $270 \mathrm{~nm}$ from 0-14 min to detect the prostaglandin $B_{2}, 235 \mathrm{~nm}$ from 15-60 min to detect monoHETEs, and a Beckman 171 Radioisotope detector for radioactivity measurements. Products were quantitated using standard molar absorption coefficients and a known mixture of prostaglandin $B_{2}$, 5,12 , and 15-HETE, and $\mathrm{C}^{14}-15$-HETE.

\section{Results}

The genomic DNA sequence of the murine preproendothelin1 (PPET-1) promoter region has not been previously determined. A clone containing the endothelin- 1 coding region (exon 
2) and more than $10 \mathrm{~kb}$ of the $5^{\prime}$-flanking promoter region was obtained. The genomic clone was verified by sequencing exon 2 which encodes the mature ET-1 peptide. This exon sequence was identical to the known murine cDNA sequence (16). Sequencing of $1,057 \mathrm{bp}$ of $5^{\prime}$-flanking region, the first exon and $200 \mathrm{bp}$ of the first intron of the murine gene (Fig. 1) revealed $67 \%$ identity to the human preproendothelin promoter (12-14). However, in some regions less than $20 \%$ identity was noted such as in the 66-bp region, +86 to +151 , and in the 76 bp region, -695 to -770 . The transcription start site, the CAAT and TATA consensus sequences, the first exon/intron junction, the GATA- 2 and the AP-1 binding site and the NF-1 binding element were identical both in sequence and in location in the murine and the human PPET-1 gene (Fig. 1). On the other hand, two other TPA-responsive elements are missing in the murine gene.

To evaluate which region of the murine preproendothelin15 '-flanking region would be useful for targeting gene expression to the vascular wall, we first constructed three plasmids with luciferase as a reporter gene directed by different 5 '-flanking regions of the murine preproendothelin gene (Fig. 2). The efficiency of each plasmid was tested by transfecting endothelial and non-endothelial cell lines and assessing luciferase activity. The plasmid containing the 5.9-kb region gave 5 and 7 times more luciferase activity in transfected bovine pulmonary artery endothelial cell line (CPAE) than the plasmids containing the 1.4 or the $0.45 \mathrm{~kb}$ regions respectively (Fig. 3). In human endothelial cells (HUVEC) p5.9mPPET-LUC gave 2-3 times more luciferase activity than the plasmids containing the 1.4- or 0.45 $\mathrm{kb}$ regions (data not shown). To assess endothelial cell specificity, endothelial and non-endothelial cell lines were transfected with either the PPET-LUC plasmids or the SV40 minimal promoter-luciferase plasmid (pGL2-control vector; Promega). All three PPET-1 constructs showed higher levels of expression in transfected endothelial than non-endothelial cell lines, with the most endothelial cell-specific construct being the p5.9mPPETLUC (Fig. 3). On the other hand non-endothelial cell lines yielded nine times more luciferase activity than did endothelial cells when transfected with constructs lacking the preproendothelin promoter (pGL2 vector). These results persuaded us to select the 5.9mPPET-LUC cassette to create the reporter transgenic mice, tg5.9mPPET-LUC.

Of the 160 live-born offspring of the tg5.9mPPET-LUC, 29 were founders as determined by luciferase activity in tail extracts and confirmed by Southern blot analysis of tail DNA using a 360-bp luciferase gene sequence as probe. Of these founders, 16 had more than 100 light units per microgram of protein of tail extract (Table I). The ability to measure luciferase expression in the mice tail, which appeared to originate from the tail vein, expedited and simplified the creation of transgenic colonies. Five independent founders with high levels of luciferase activity in tails ( $>950$ light units per $\mu$ g protein) were crossbred for several generations with wild type C57B6/SJL mice to establish heterozygous colonies tg5.9mPPET-LUC 1 to 5 , with the highest level of expression in colony 2 and the lowest in colony 1 .

To study the tissue distribution of the luciferase gene directed by the murine PPET-1 promoter, 31 transgenic mice from the 5 colonies established from independent founders and 8 nontransgenic mice were sacrificed at the age of $3 \mathrm{mo}$. Luciferase activity was measured in different organs as described in the Methods. In all transgenic mice, the highest level of expres-
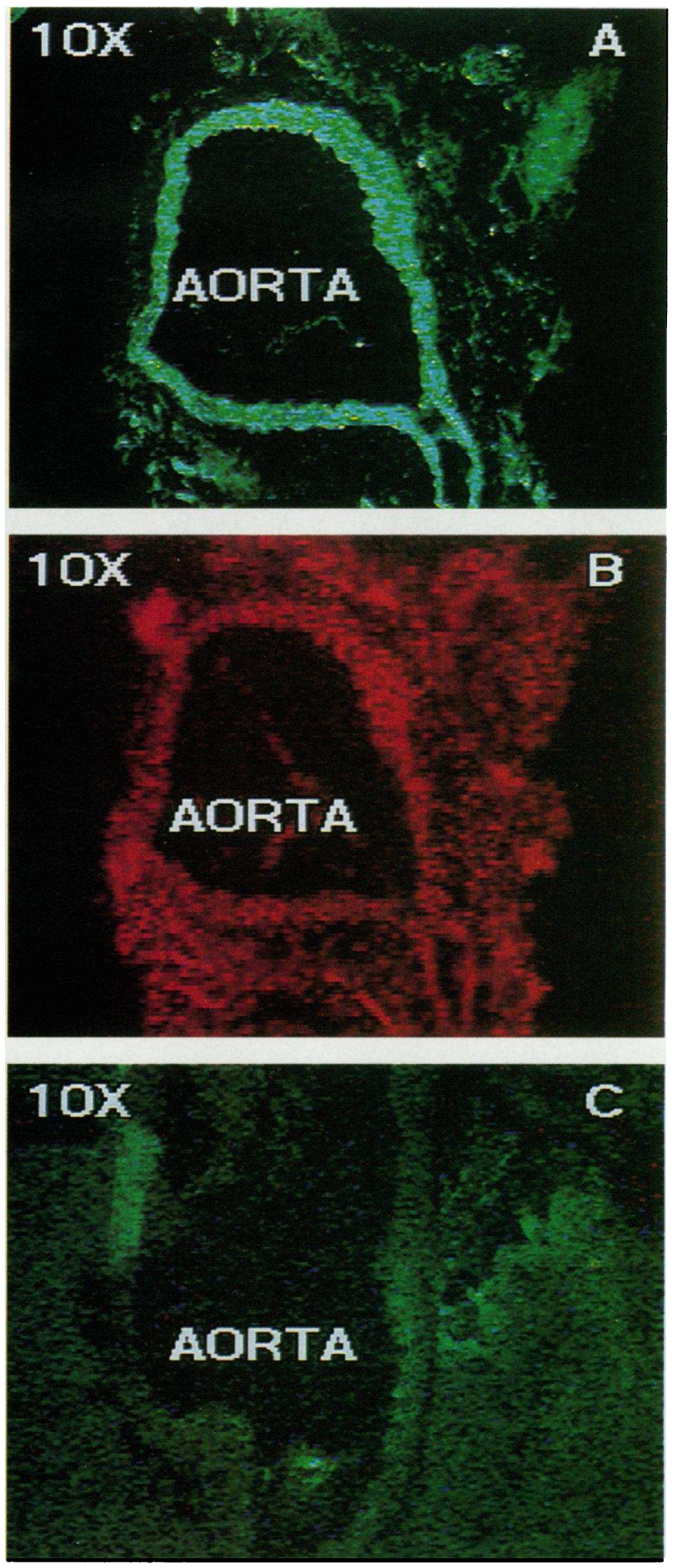

Figure 5. Immunohistochemistry sections of the aorta of tg5.9mPPETLUC and control mice. Frozen aortic sections were prepared for immunofluorescent staining of luciferase as in Methods. $(A)$ Aortic section $(\times 10)$ of a transgenic mouse tg5.9mPPET-LUC stained with anti-luciferase antisera, showing specific staining for luciferase in the aortic wall (intima and media). $(B)$ Aortic section $(\times 10)$ of a transgenic mouse tg5.9mPPET-LUC stained with propidium iodide to detect cell nuclei. (C) a control, aortic section (10×) of PPET-15LO (nonrelevant transgenic mice) stained with anti-luciferase antisera with no specific staining for luciferase. 

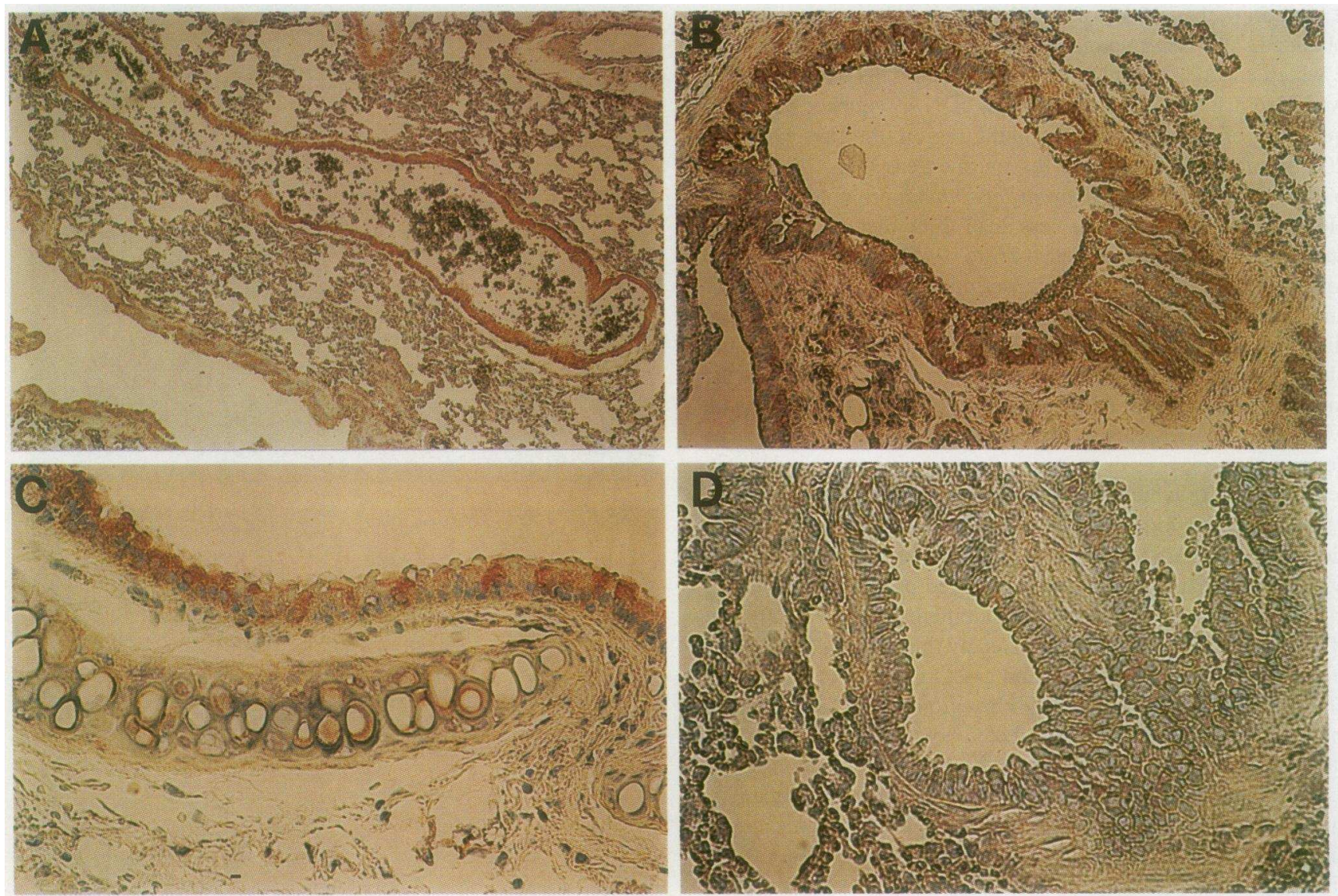

Figure 6.
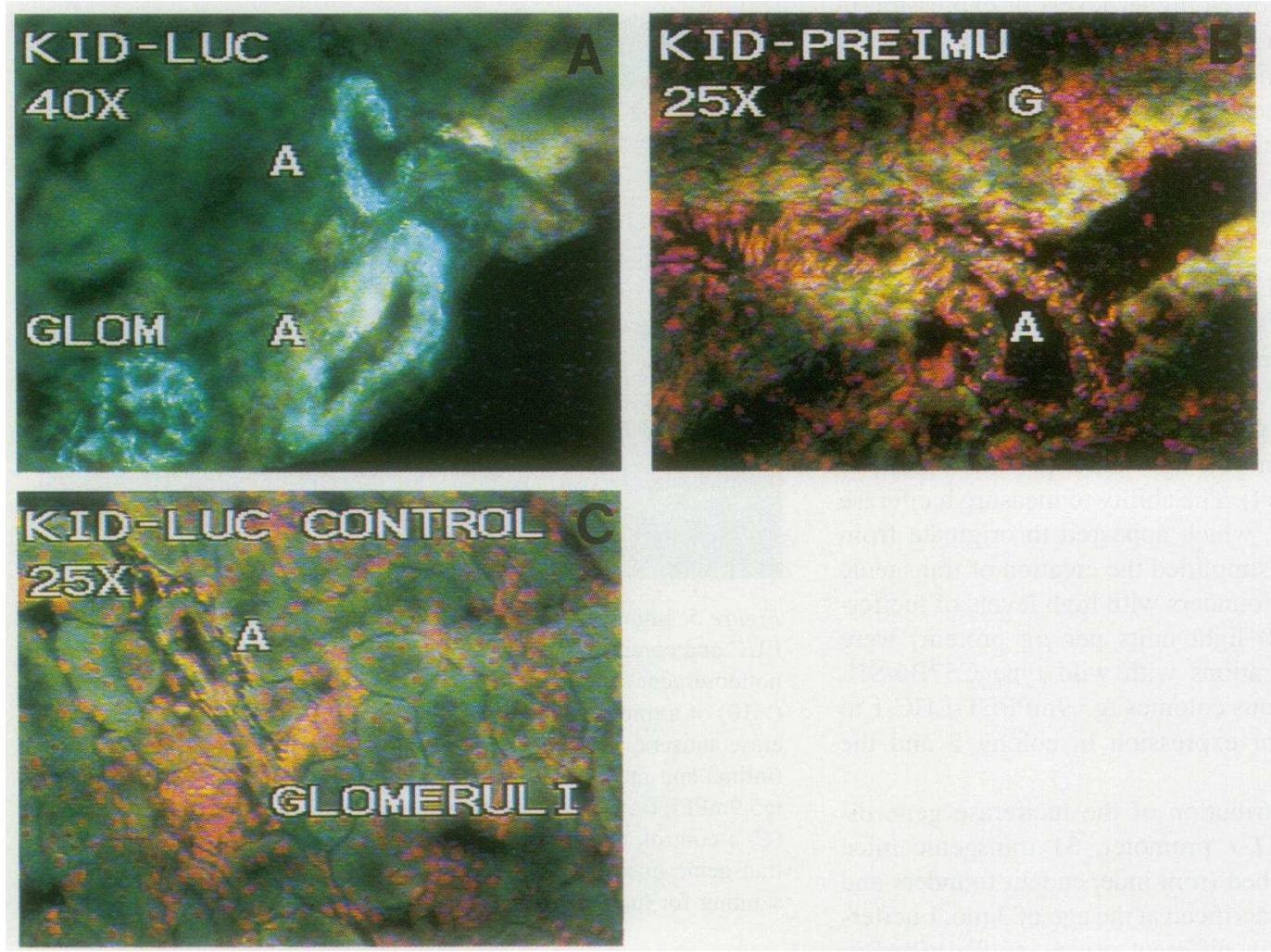

Figure 7. 
sion was in the aorta. Although the different colonies showed different levels of luciferase expression, the tissue distribution was identical as shown for the lowest and the highest expressing colonies in Fig. 4.

The cellular distribution of expression in the aorta was studied next. Mouse aortic endothelial cells were selected by lectin magnetic beads, and cultured from 5 transgenic, and 5 nontransgenic mice. The "endothelial" fraction had $90 \%$ endothelial cells, and the "non-endothelial" fraction had $<10 \%$ endothelial cells, as determined by endothelial specific staining with anti-Von Willebrand antibody (data not shown). The luciferase activity was 4.3 times higher in the "endothelial" than in the "non-endothelial" cell fraction (41,750 and 9,673 light units/ $2 \times 10^{5}$ cells, respectively).

Immunohistochemical staining of the aorta (Fig. 5) showed high levels of luciferase expression in the aortic wall (Fig. $5 \mathrm{~A}$ ) but not in the surrounding tissue as shown by nuclear staining with propidium iodide (Fig $5 \mathrm{~B}$ ). Endothelial-specific staining with anti-Von Willebrand antibody, and smooth muscle cellspecific staining with anti-actin antibody (data not shown) indicated that the luciferase expression was in the intima (endothelial cells), the media (smooth muscle cells), as well as the vasa vasorum. Staining of the aorta from 5.9PPET-LUC transgenic mice with preimmune serum and the aorta of a PPET-15LO transgenic control mice with anti-luciferase antisera (Fig. 5 C) were both negative. High levels of expression were also noted in other large arteries, in small muscular arteries, and to a lesser extent in capillaries throughout the body (Figs. 6-7). Lower levels of expression were noted in veins. Some organs such as the heart, kidney, and lung showed more vascular expression than others. The liver and the spleen showed minimal vascular expression. Even in the same organ some arteries showed high levels of expression while others showed little or none (Figs. 6 and 7). In large, muscular arteries the expression was in the intima and media (Fig. $5 A$, and Fig. $7 A$ ), but in small arteries, veins and capillaries the expression was confined to the endothelial cells.

In most organs the expression was confined to the vascular tissue, however, some nonvascular expression was detected as shown for the lung and the kidney (Figs. 6 and 7). The most significant nonvascular expression was detected in the airway epithelium as indicated by luciferase activity in the trachea (Fig. 4) and by anti-luciferase staining of the lung (Fig. 6). Similar expression was detected in salivary gland epithelium. The glomeruli showed high levels of expression both in the endothelial and the mesangial cells (Fig. $7 \mathrm{~A}$ ). The epithelium of the small intestine showed expression that increased gradually from the basal cells (no expression) toward the mature cells lining the lumen. Different regions of the brain showed different levels of luciferase expression (data not shown). This pattern was identical to the published distribution of endothelin expression in the brain (10). Other select nonvascular cells showed much lower levels of luciferase activity. The pattern of immunofluorescence staining of frozen sections was confirmed by peroxidase staining of paraffin sections.

To further demonstrate the targeting capability of this system, we then used the 5 '-flanking sequence of the murine preproendothelin-1 gene to express the human 15-lipoxygenase in transgenic mice as described in Methods. We have established two heterozygous colonies from independent founders. Mice from each colony have been analyzed for the expression of the heterologous 15-lipoxygenase enzyme by immunocytochemistry using an anti-human 15-lipoxygenase antibody. All mice analyzed have shown 15-lipoxygenase expression in the vascular wall of various organs as illustrated for the coronary and pulmonary arteries in Figs. 8 and 9 respectively. In nonvascular tissue, the highest expression was again observed in the airway epithelium (Fig. 9). Other nonvascular tissues showed minimal or no expression. The pattern of the vascular and non-vascular expression was similar to the luciferase expression as described above. Nontransgenic mice stained with 15-lipoxygenase antibody showed no immunoreactivity (Fig. 8 and 9). In addition, transgenic mice stained with non-immune rabbit IgG as a further control showed no immunoreactivity (data not shown).

To confirm that the human 15-lipoxygenase expressed in the transgenic mice is enzymatically active we performed activity assays on various tissues and measured the enzyme product 15HETE, as shown in Table II. In extracts of heart tissue from transgenic mice, $4.43 \pm 0.99 \mathrm{ng} 15$-HETE was detected per $\mathrm{mg}$ tissue $(n=8)$. This was significantly different $(P<0.01)$ from levels obtained from extracts of heart tissue of non-transgenic mice $(0.026 \pm 0.03, n=5)$. In aortic tissues of transgenic mice $5.86 \pm 0.49 \mathrm{ng} 15$-HETE per mg tissue was detected. Aortas of non-transgenic mice contained no detectable 15-HETE production. 15-HETE was also detected in tracheas and brains of transgenic mice $(3.56 \pm 1.18$ and $0.27 \pm 0.06 \mathrm{ng} / \mathrm{mg}$ tissue respectively, $n=5)$ but not in non-transgenic mice $(0.11 \pm 0.005$ and $0.005 \pm 0.002 \mathrm{ng} / \mathrm{mg}$ tissue respectively, $n=3$ ). Both differences were statistically significant $(p<0.05$ and $p<0.01$ respectively). No 15-HETE was detected in the livers of transgenic or nontransgenic mice. It is of interest that in the trachea the levels of 15-HETE (which is the product of the human 15lipoxygenase) were up to 7 times higher than that of 12-HETE which is the product of the murine 12-lipoxygenase normally expressed in this organ.

Figure 6. Immunohistochemistry of lung and trachea sections of tg5.9mPPET-LUC mice and nontransgenic mice. Paraffin sections of lung and trachea were stained with anti-luciferase antisera and detected with immunoperoxidase as in Methods. ( $A$ ) Lung section (10 $\times$ ) of a transgenic mouse showing specific staining for luciferase in large blood vessel and airways. $(B)$ Lung section $(25 \times)$ of a transgenic mouse showing specific staining for luciferase in the airway epithelium. $(C)$ Trachea section $(100 \times)$ of a transgenic mice showing specific staining for luciferase in each cell of the airway epithelium. $(D)$ Lung section $(25 \times)$ of a nontransgenic mice showing no specific staining for luciferase.

Figure 7. Immunohistochemistry of kidney sections of tg5.9mPPET-LUC and non-transgenic mice. Frozen kidney sections were prepared for immunofluorescent staining of luciferase as in Methods. $(A)$ Kidney section of the transgenic mice tg5.9mPPET-LUC stained with anti-luciferase antisera and counterstained with propidium iodide, showing specific staining for luciferase in the glomeruli and in an arteriole. (B) Kidney section of the transgenic mice tg5.9mPPET-LUC stained with preimmune sera and counterstained with propidium iodide, showing no staining for luciferase. (C) Kidney sections of nontransgenic mice stained with anti-luciferase antisera and counterstained with propidium iodide, showing no staining for luciferase. The sections were viewed with a dual green/red filter. $A$, arteriole; $G$, glomerulus. 

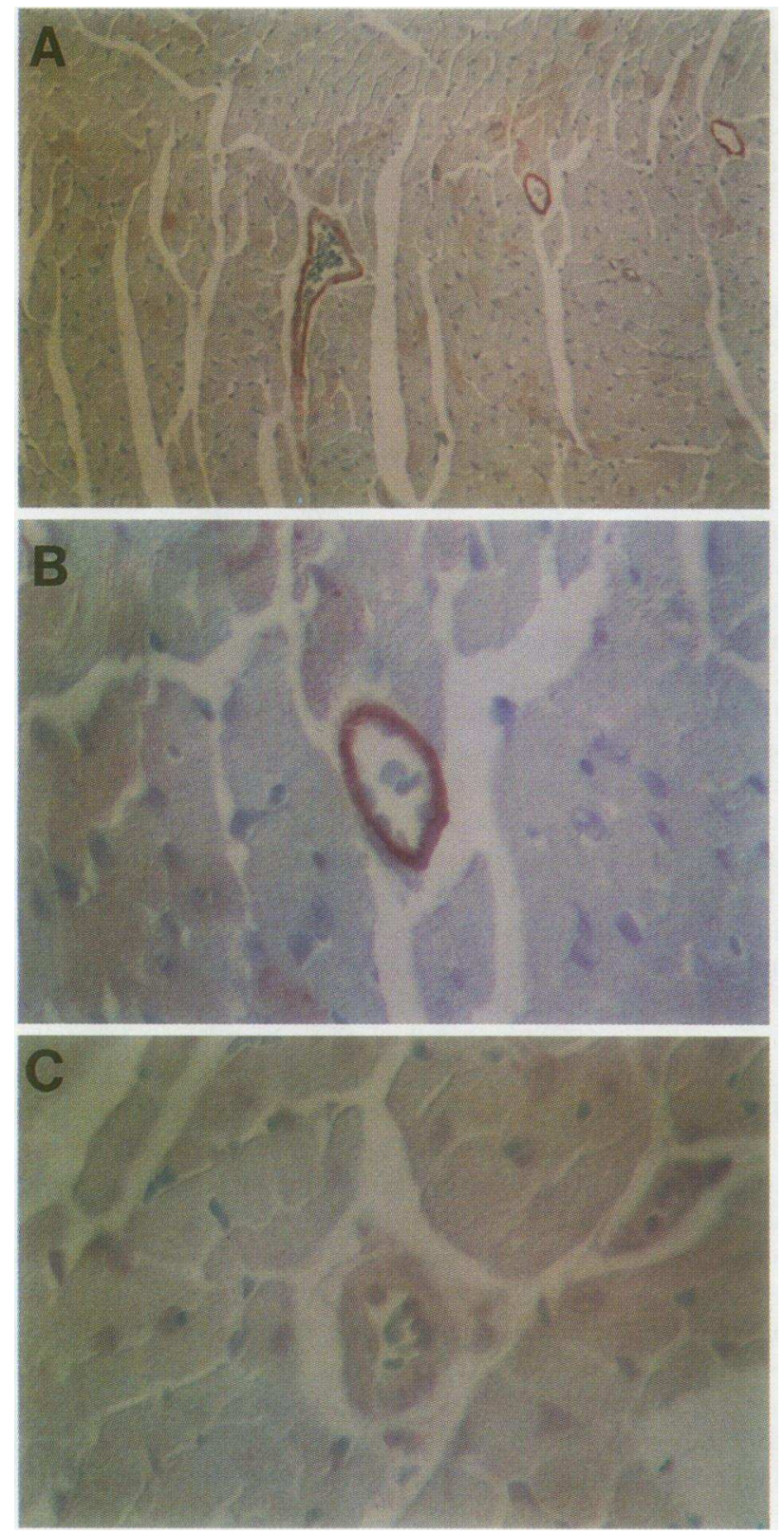

Figure 8. Immunohistochemistry of heart sections of the PPET-15LO transgenic mice and nontransgenic mice. Paraffin sections of heart were stained with rabbit anti-human 15-lipoxygenase antibody $(1: 2,000)$ and detected with immunoperoxidase as in Methods. $(A)$ Heart section of a PPET-15LO transgenic mouse $(25 \times)$ and $(B)$ Heart section of a PPET15LO transgenic mouse $(40 \times)$ showing specific expression of 15-lipoxygenase in the coronary arteries of the transgenic mice. $(C)$ Heart section of a nontransgenic mouse $(40 \times)$ showing no staining for 15-lipoxygenase.

\section{Discussion}

Our data show that the murine preproendothelin promoter sequence can be used to direct significant in vivo gene expression to the vascular wall in transgenic mice. Expression in select epithelial cells, particularly those of the airway also occurs. However, expression in most non-vascular tissues is minor or non-existent. To avoid potential species differences in expression, we cloned the murine PPET-1 gene 5'-flanking region.
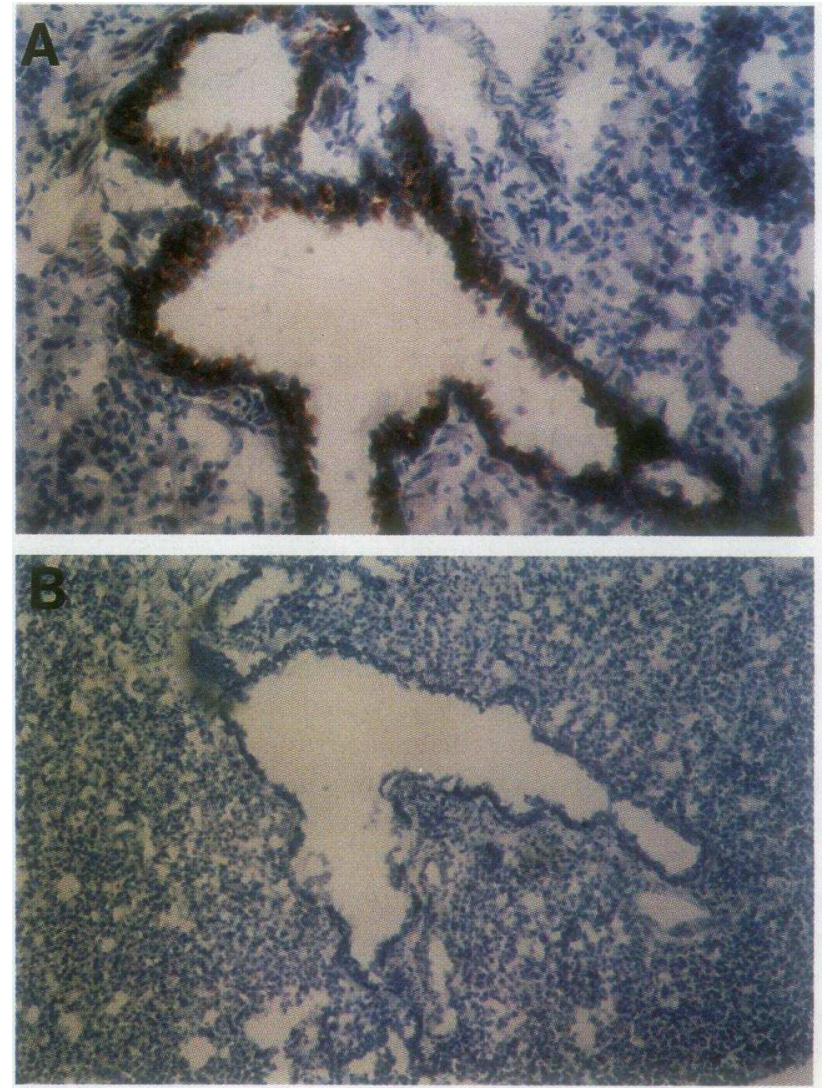

Figure 9. Immunohistochemistry of lung sections of the PPET-15LO mice and nontransgenic mice. Frozen lung sections were stained with rabbit anti-human 15-lipoxygenase antibody $(1: 2,000)$ and detected with immunoperoxidase as in Methods. $(A)$ Lung section of a PPET-15LO transgenic mouse ( $40 \times$ ) showing specific expression of 15-lipoxygenase in the airway epithelium. $(B)$ Lung section of a non-transgenic mouse $(25 \times)$ showing no staining for 15-lipoxygenase.

Sequencing of $1 \mathrm{~kb}$ of the 5 -flanking region yielded $67 \%$ identity with the published human sequence. The observation that in vitro transfection efficiency did not vary between constructs using $0.45 \mathrm{~kb}$ versus $1.4 \mathrm{~kb}$ of $5^{\prime}$-flanking region is similar to that reported for the human promoter analysis (11-14). However, our results suggests that the -1.4 to $-5.9 \mathrm{~kb}$ region may contain endothelial cell-specific elements, although further work is needed to confirm this. In any event, this study clearly suggests that larger fragments of the murine promoter are preferred when attempting tissue specific expression. This has not been the experience with the human gene $(11-12)$. Five colonies of the tg5.9mPPET-LUC mice have been established and all five showed the same distribution of luciferase activity and immunostaining, suggesting that expression is unlikely to be very dependent on integration site. The most significant expression of luciferase was in the aorta and the vasculature throughout the body, but some organs showed more vascular expression than others. Even in the same organ some arteries showed high expression while others showed little or no expression. In addition, expression was often in the intima and media of large muscular arteries but only in endothelial cells in other vessels. Such uneven expression of endothelin within the vasculature of the same organ and from organ to organ has been previously described (4-10, 26). In nonvascular cells the most significant expression was in 
Table II. 15-Lipoxygenase Expression in Tissue Extracts of 3-moold Transgenic and Nontransgenic Mice, as Detected by Measuring the Production of the 15-lipoxygenase Metabolite, 15HETE from Arachidonic Acid

\begin{tabular}{|c|c|c|c|c|c|}
\hline & \multicolumn{2}{|r|}{ Transgenic } & \multicolumn{2}{|c|}{ Nontransgenic } & \multirow[b]{2}{*}{$\mathbf{P}$} \\
\hline & $n$ & $\begin{array}{c}\text { 15-HETE* } \\
\mathrm{ng} / \mathrm{mg} \text { tissue }\end{array}$ & $n$ & $\begin{array}{l}\text { 15-HETE* } \\
\mathrm{ng} / \mathrm{mg} \text { tissue }\end{array}$ & \\
\hline Brain & 5 & $0.270 \pm 0.060$ & 3 & $0.005 \pm 0.002$ & $P<0.01$ \\
\hline Trachea & 5 & $3.560 \pm 1.180$ & 3 & $0.115 \pm 0.005$ & $P<0.05$ \\
\hline Heart & 8 & $4.430 \pm 0.990$ & 5 & $0.026 \pm 0.030$ & $P<0.01$ \\
\hline Aorta & $3^{\ddagger}$ & $5.860 \pm 0.490$ & $3^{\ddagger}$ & $<0.001$ & $\mathrm{P}<0.01$ \\
\hline Liver & 4 & $<0.001$ & 3 & $<0.001$ & N.S. \\
\hline
\end{tabular}

* Levels of 15-HETE produced from exogenous substrate using Arachidonic acid as described in Methods. ${ }^{\ddagger}$ Aortas from nine different mice were analyzed, each three combined as one sample.

the respiratory epithelium which is not surprising since these cells are known to express endothelin-1, although at a lower level than endothelial cells (5).

Hence, the pattern of vascular and non-vascular expression of luciferase in the transgenic mice is generally consistent with the previously described distribution of endothelin in mammals $(4-10,26)$. Minor differences in tissue distribution from this study and other reports would not be surprising since endothelin is a secretory protein with an unstable mRNA. Moreover, endothelin has a high sequence identity with other members of the endothelin family that includes endothelin-2 and endothelin-3 $(27-31)$. On the other hand, luciferase is a nonsecretory protein that has a stable mRNA and does not cross react in immunostaining with other murine proteins. Therefore the described system may offer distinct advantages in studying mechanisms of the regulation of endothelin-1 expression over analysis of endogenous gene products. Clearly, the transgenic mice described here will be valuable in studying the PPET-1 promoter in vivo.

Upon completion of this study we learned of an attempt to use the human preproendothelin-1 5'-flanking region to direct $\beta$-galactosidase expression to the vascular wall in transgenic mice (32). The authors concluded that the levels of expression were too low to be of significant use as a gene targeting system. No $\beta$-galactosidase activity was reported, although immunostaining was observed. While endothelin-1 mRNA is easily detected by Northern analysis, the $\beta$-galactosidase transcripts in these mice could only be detected by reverse transcriptasepolymerase chain reaction (RT-PCR) and RNase protection. Moreover, some transgenic colonies did not show the same tissue distribution as expected with endothelin- 1 and all of them had an unexplained expression in heart muscle cells. The authors suggest that some important regulatory elements are missing in their construct. In contrast, we have shown high, consistent levels of luciferase expression in the same distribution as expected for endothelin-1. Although luciferase is a more sensitive reporter gene than $\beta$-galactosidase, the levels that we obtained in all five colonies were up to five times higher than published luciferase expression levels in transgenic mice (3338). Moreover, we showed that significant expression of the human 15-lipoxygenase can be directed to the vascular wall and the airway epithelium.
It is not certain whether species differences alone explain the differences between the two studies. We used the 5.9-kb 5 -flanking region of the murine promoter sequence that may have an endothelial specific element between -1.4 and -5.9 $\mathrm{kb}$ as discussed. We also include in our construct the first exon and $0.8 \mathrm{~kb}$ of the first intron. The human construct had only $4.4 \mathrm{~kb}$ of the 5 '-flanking human endothelin-1 promoter region sequence and no elements from the first exon or intron.

The murine preproendothelial targeting system achieved not only significant luciferase expression but expression of a biologically relevant gene product. Because 15-lipoxygenase is a lipid peroxidating enzyme capable of oxidating low density lipoproteins in vitro, it will be of interest to observe whether foam cells appear more readily in these transgenic mice. This will require cholesterol feeding after crossbreeding of the described heterozygotes to achieve appropriate genetic background. These studies can now be pursued.

Because the murine PPET-1 promoter sequence can direct expression of genes to the vascular wall in transgenic mice, a number of experiments addressing in vivo physiology and pathophysiology will be possible. Overexpression of select proteins will permit in vivo evaluation of biological sequelae that have been suggested from in vitro data. Moreover, expression of peptide inhibitors, soluble receptors, anti-sense RNA or other molecules that may not be bioavailable will allow the elucidation of in vivo vascular biology that would otherwise be difficult to assess. Furthermore, the ability to knock-out function in a restricted fashion may offer advantages over systemic approaches which effect a variety of systems and sometimes lead to lethal phenotypes. Finally, as gene therapy becomes more feasible, it is clear that one of its limitations is the inability to direct expression to the desired cells. Both the endothelial cells and airway epithelial cells are important targets for gene therapy in diseases such as atherosclerosis, restenosis, and cystic fibrosis. The current study suggests that preproendothelin 5 '-flanking sequence may augment the ability to achieve expression in select somatic cells in gene therapy.

\section{Acknowledgments}

We thank Professor Yazaki for support in the early stages of the murine preproendothelin-1 cloning, Dr. John Caulfield for his useful suggestions in developing the anti-luciferase immunostaining, and Dr. Randall Schatzman and Judy L. Haller for their help in developing the antiluciferase antibody.

This work was supported in part by the National Institutes of HealthFogarty International Fellowship Grant (5 FO5 TW04804-02), the Israel Academy of Sciences-Wolfson fellowship Grant, and the Council for Tobacco Research.

\section{References}

1. Ross, R. 1993. The pathogenesis of atherosclerosis: a perspective for the 1990s. Nature (Lond.). 362:801-809.

2. Yanagisawa, M., H. Kurihara, S. Kimura, Y. Tombe, M. Kobayashi, Y. Mitsui, Y. Yazaki, K. Goto, and T. Masaki. 1988. A novel potent vasoconstrictor peptide produce by vascular endothelial cells. Nature (Lond.). 332:411-415.

3. Sakurai, T., M. Yanagisawa, A. Lnoue, U. S. Ryan, S. Kimura, Y. Mitsui, K. Goto, and T. Masaki. 1991. cDNA cloning, sequence analysis and tissue distribution of rat preproendothelin-1 mRNA. Biochem. Biophys. Res. Commun. 175:44-47.

4. MacCumber, M. W., C. A. Ross, B. M. Glaser, and S. H. Snyder. 1989. Endothelin: Visualisation of mRNA by in situ hybridization provides evidence for local action. Proc. Natl. Acad. Sci. USA. 86:7285-7289.

5. Filep, J. G. 1993. Endothelin peptides: Biological actions and pathophysiological significance in the lung. Life Sciences. 52:119-133. 
6. Kasinath, B. S., T. A. Fried, S. Davalath, and P. A. Marsden. 1992. Glomerular epithelial cells synthesize endothelin peptides. Am. J. Pathol. 141:279-283.

7. Marsden, P. A., D. M. Dorfman, T. Collins, B. M. Brenner, S. H. Orkin and B. J. Ballermann. 1991. Regulated expression of endothelin 1 in glomerular capillary endothelial cells. Am. J. Physiol. 261:F117-F125.

8. Resnik, T. J., A. W. A. Hahn, T. Scott-Burden, J. Powell, E. Weber, and F. R. Bühler. 1990. Inducible endothelin mRNA expression and peptide secretion in cultured human vascular smooth muscle cells. Biochem. Biophys. Res. Commun. 168:1303-1310.

9. Ujiie, K., Y. Terada, H. Nonoguchi, M. Shinohara, K. Tomita, and F. Marumo. 1992. Mesenger RNA expression and synthesis of endothelin-1 along rat nephron segments. J. Clin. Invest. 90:1043-1048.

10. Lee, M., S. M. de la Monte, S. Ng, K. D. Bloch, and T. Quertermous 1990. Expression of the potent vasoconstrictor endothelin in the human central nervous system. J. Clin. Invest. 86:141-147.

11. Wilson, D. B., D. M. Dorfman, and S. H. Orkin. 1990. A nonerythroid GATA-binding protein is required for function of the human preproendothelin-1 promoter in endothelial cells. Mol. Cell. Biol. 10:4854-4862.

12. Lee, M., K. D. Bloch, J. A. Clifford, and T. Quertermous. 1990. Functiona analysis of the endothelin-1 gene promoter. J. Biol. Chem. 265: 0446-0450.

13. Lee, M., D. H. Temizer, J. A. Clifford, and T. Quertermous. 1991. Cloning of the GATA-binding protein that regulates endothelin-1 gene expression in endothelial cells. J. Biol. Chem. 266:16188-16192.

14. Bloch, K. D., S. P. Friedrich, M. Lee, R. L. Eddy, T. B. Shows, and T. Quertermous. 1989. Structural organization and chromosomal assignment of the gene encoding endothelin. J. Biol. Chem. 264:0851-10857.

15. Ylä-Herttuala, S., M. E. Rosenfeld, S. Parthasarthy, C. K. Glass, E. Sigal, J. L. Witztum, and D. Steinberg. 1993. Colocalization of 15-lipoxygenase mRNA and protein with epitopes of oxidized low density lipoprotein in macrophage-rich areas of atherosclerotic lesions. Proc. Natl. Acad. Sci. USA. 87:6959-6963.

16. Saida, K., Y. Mitsui, and N. Ishida. 1989. A novel peptide, vasoactive intestinal contractor, of a new (endothelin) peptide family. J. Biol. Chem 264:4613-14616.

17. Maniatis, T., E. F. Fritsch, and J. Sambrook. 1989. Molecular Cloning: A Laboratory Manual, 2nd edition. Cold Spring Harbor Laboratory Press, Cold Spring Harbor, NY.

18. Hogan, B., F. Costantini, and E. Lacy. 1986. Manipulating the Mouse Embryo. Cold Spring Harbor Laboratory, Cold Spring Harbor, NY. 331 pp.

19. Sigal, E. , C. S. Craik, E. Highland, D. Grunberger, L. L. Costello, R. A. F. Dixon, and J. A. Nadel. 1988. Molecular cloning and primary structure of human 15-lipoxygenase. Biochem. Biophys. Res. Commun. 157:457-464.

20. Felgner, P. L., T. R. Gadek, M. Holm, R. Roman, H. W. Chan, M. Wenz, J. P. Northrop, G. M. Ringold, and M. Danielsen. 1987. Lipofection: a highly efficient, lipid-mediated DNA-transfection procedure. Proc. Natl. Acad. Sci. USA. 84:7413-7417.

21. Bradford, M. M. 1976. A rapid and sensitive method for the quantitation of nanogram quantities of protein utilizing the principle of protein-dye binding. Anal. Biochem. 72:248-254.

22. Belloni, P. N., D. H. Carney, and G. L. Nicholson. 1992. Organ-derived microvessel endothelial cells exhibit differential responsiveness to thrombin and other growth factors. Microvasc. Res. 43:20-45.

23. Sigal, E., D. Grunberger, E. Highland, C. Gross, R. A. F. Dixon, and C. S. Craik. 1990. Expression of cloned human reticulocyte 15-lipoxygenase and immunological evidence that 15-lipoxygenases of diferent cell type are related J. Biol. Chem. 265:5113-5120.

24. Sigal, E., S. Dicharry, E. Highland, and W. F. Finkbeiner. 1992. Cloning of human airway 15 lipoxygenase: identity to the reticulocyte enzyme and expression in epithelium. Am. J. Physiol. 262:L392-L398.

25. Simon, T. C., A. N. Makheja, and J. M. Bailey. 1989. Formation of 15hydroxyeicosatetraenoic acid (15-HETE) as the predominant eicosanoid in aortas from Watanabe Heritable Hyperlipidemic and cholesterol-fed rabbits. Atherosclerosis. 75:31-38.

26. Nunez, D. J. R., M. J. Brown, A. P. Davenport, C. B. Neylon, J. P. Schofield, and R. K. Wyse. 1990. Endothelin-1 mRNA is widely expressed in porcine and human tissues. J. Clin. Invest. 85:537-1541.

27. Inoue, A., M. Yanagisawa, S. Kimura, Y. Kasuya, T. Miyauchi, K. Goto, and T. Masaki. 1989. The human endothelin family: Three structurally and pharmacologically distinct isopeptides predicted by three separate genes. Proc. Natl. Acad. Sci. USA. 86:2863-2867.

28. Bloch, K. D., R. L. Eddy, T. B. Shows, and T. Quertermous. 1989. cDNA cloning and chromosomal assignment of the gene encoding endothelin-3. J. Biol. Chem. 264:18156-18161.

29. Saida, K., and Y. Mitsui. 1991. Structure of the precursor for the vasoactive intestinal contractor (VIC): its comparison with those of endothelin-1 and endothelin-3. J. Cardiovasc. Pharmacol. 17:(suppl. 7):S55-S58.

30. Bloch, K. D., C. C. Hong, R. L. Eddy, T. B. Shows, and T. Quertermous 1991. cDNA cloning and chromosomal assignment of the endothelin- 2 gene: vasoactive intestinal contractor peptide is rat endothelin-2. Genomics. 10:236242.

31. Saida, K., and Y. Mitsui. 1991. cDNA cloning, sequence analysis and tissue distribution of a precursor for vasoactive intestinal contractor (VIC). Biochim. Biophys. Acta. 1089:404-406.

32. Hilkert, R. J., S. de la Monte, M. Lee, J. S. Yum, T. E. Wagner, and T. Quertermous. 1993. Transgene expression directed by endothelin-1 promoter is cell-type-specific but integration-site-dependent. J. Vasc. Med. Biol. 4:138-147.

33. Lee, K. J. R. S. Ross, H. A. Rockman, A. N. Harris, T. X. O’Brien, M van Bilsen, H. E. Shubieta, R. Kandolf, G. Brem, J. Price, S. M. Evans, H. Zhu, W. M. Franz, and K. R. Chein. 1992. Myosin light chain-2 luciferase transgenic mice reveal distinct regulatory programs for cardiac and skeletal muscle-specific expression of a single contractile protein gene. J. Biol. Chem. 267:15875-15885.

34. O'Brien, T. X., K. J. Lee, and K. R. Chein. 1993. Positional specification of ventricular myosin light chain 2 expression in the primitive murine heart tube. Proc. Natl. Acad. Sci. USA. 90:5157-5161.

35. Robinson, M. O., J. R. McCarrey, and M. I. Simon. 1989. Transcriptional regulatory regions of testis-specific PGK2 defined in transgenic mice. Proc. Natl. Acad. Sci. USA. 86:8437-8441.

36. Niederreither, K., R. N. D’Souza, and B. de Crombrugghe. 1992. Minimal DNA sequences that control the cell lineage-specific expression of the proa2(I) collagen promoter in transgenic mice. J. Cell Biol. 119:1361-1370.

37. Lira, S. A., R. A. Kinloch, S. Mortillo, and P. M. Wassarman. 1990. An upstream region of the mouse ZP3 gene directs expression of firefly luciferase specifically to growing oocytes in transgenic mice. Proc. Natl. Acad. Sci. USA. 87:7215-7219.

38. Schichler, M., S. A. Lira, R. A. Kinloch, and P. M. Wassarman. 1992. A mouse oocyte-specific protein that binds to a region of $\mathrm{mZP} 3$ promoter responsible for oocyte-specific mZP3 gene expression. Mol. Cell. Biol. 12:120-127. 